\section{Cephalosporins with the (E)-Thiovinyl Linker with Pyrimidine at C-3 Position Exhibiting Potent Activities against Gram-positive Strains}

\author{
Geun Tae Kim, * Yong-Jin Jang, Eun-Jung Ryu, \\ Ki Dong Koo, Chang-Seok Lee, ${ }^{*}$ Hasik Youn, \\ YAng Rae Cho and Hyung Yeul JoO
}

LG Life Science, Ltd.

R\&D Park 104-1 Munji-dong, Yuseong-gu, Taejon 305-380, Korea

(Received for publication April 12, 2004)

Cephalosporins have been used to treat many pathogens in the clinic. However, the emergence of multidrug-resistant strains of Gram-positive bacteria caused the nosocomial infection has become a major concern. ${ }^{1,2)}$ Antimicrobial agents like vancomycin, quinupristin/dalfopristin $(\text { Synercid) })^{3)}$ and linezolid (Zyvox) ${ }^{4)}$ were developed to manage infections such as complicated skin and skin structure infection and life-threatening bacteremia. The recently isolated pathogens from hospitals are likely to reduce susceptibility to those drugs. ${ }^{5)}$ Therefore, urgent need of a new agent with good safety and potent efficacy against MRSA and VRE has led us to search for a new cephalosporin. Herein, we described the synthesis of cephalosporins having the (E)-thiovinyl linker with pyrimidines ring at $\mathrm{C}-3$ position and aminothiazole rings at C-7 position and their antibacterial activities as well.

\section{Chemistry}

Cephalosporin with the (E)-thiovinyl linker at C-3 position were known to possess good in vitro antibacterial activities against MRSA and vancomycin-resistant Enterococcus faecalis. ${ }^{6}$ Therefore we applied the (E)thiovinyl linker with pyrimidines at C-3 position to develop a new and effective cephalosporin with excellent activities against MRSA and VRE in our communication. This approach would show the scope of activities of cephalosporins with the (E)-thiovinyl linker having pyrimidines at $\mathrm{C}-3$ position.

All the cephalosporins and pyrimidinethiols ${ }^{7)}$ we prepared were described in Fig. 1. Among those cephalosporins, representative 1c was synthesized as described in Scheme 1. In the beginning, the commercially available cephalosporin 3 was coupled with acid 4 using phosphorus oxychloride $\left(\mathrm{POCl}_{3}\right)$ and pyridine in dichloromethane at $-20^{\circ} \mathrm{C}$ to produce amide 5 . Treatment of 5 with Bredereck's reagent ${ }^{8)} t-\mathrm{BuOCH}\left(\mathrm{NMe}_{2}\right)_{2}$ afforded enamine, which was hydrolyzed with $1 \mathrm{~N} \mathrm{HCl}$ to give aldehyde $\mathbf{6}$. The proper leaving group should be chosen for the formation of vinyl sulfide. Reaction of aldehyde $\mathbf{6}$ with $p$-toluenesulfonyl chloride, methanesulfonyl chloride, chlorine and trifluoromethanesulfonic anhydride gave the corresponding vinyl tosylate, vinyl mesylate, vinyl chloride and vinyl triflate, respectively. While displacement of vinyl tosylate, vinyl mesylate and vinyl chloride with pyrimidinethiols in Fig. 1 was too sluggish or turned out to give low chemical yield (5 10\%), transformation of vinyl triflate to vinyl sulfide was proven to be successful. It was worthwhile to note that vinyl triflate was an appropriate leaving group to handle with good stability. The generated vinyl triflate 7 was reacted with pyrimidinethiol 2a to afford

Fig. 1.

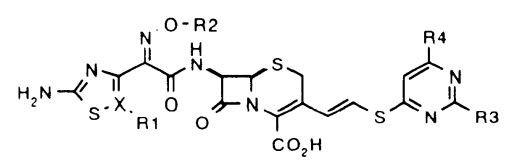

1

SAr $=$<smiles></smiles>

$2 a$

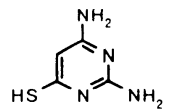

2b

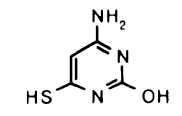

2c

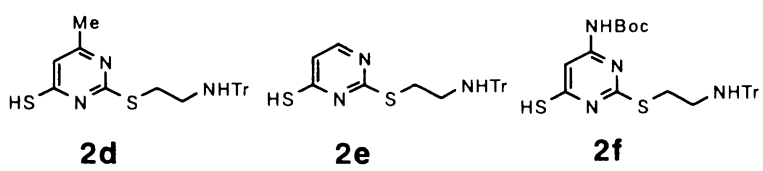

\begin{tabular}{ccccccc}
\hline No & $\mathrm{X}$ & $\mathrm{R} 1$ & $\mathrm{R} 2$ & $\mathrm{R} 3$ & $\mathrm{R} 4$ & $\mathrm{SAr}$ \\
\hline $\mathbf{1 a}$ & $\mathrm{C}$ & $\mathrm{H}$ & $\mathrm{Me}$ & $\mathrm{NH}_{2}$ & $\mathrm{OH}$ & $\mathbf{2 a}$ \\
$\mathbf{1 b}$ & $\mathrm{C}$ & $\mathrm{H}$ & $\mathrm{H}$ & $\mathrm{NH}_{2}$ & $\mathrm{OH}$ & $\mathbf{2 a}$ \\
$\mathbf{1 c}$ & $\mathrm{C}$ & $\mathrm{Cl}$ & $\mathrm{H}$ & $\mathrm{NH}_{2}$ & $\mathrm{OH}$ & $\mathbf{2 a}$ \\
$\mathbf{1 d}$ & $\mathrm{C}$ & $\mathrm{Cl}$ & $\mathrm{H}$ & $\mathrm{NH}_{2}$ & $\mathrm{NH}_{2}$ & $\mathbf{2 b}$ \\
$\mathbf{1 e}$ & $\mathrm{C}$ & $\mathrm{Cl}$ & Cyclo- & $\mathrm{NH}_{2}$ & $\mathrm{NH}_{2}$ & $\mathbf{2 b}$ \\
& & & pentyl & & & \\
$\mathbf{1 f}$ & $\mathrm{C}$ & $\mathrm{Cl}$ & $\mathrm{H}$ & $\mathrm{OH}$ & $\mathrm{NH}_{2}$ & $\mathbf{2 c}$ \\
$\mathbf{1 g}$ & $\mathrm{N}$ & - & $\mathrm{H}$ & $\mathrm{NH}_{2}$ & $\mathrm{NH}_{2}$ & $\mathbf{2 b}$ \\
$\mathbf{1 h}$ & $\mathrm{C}$ & $\mathrm{Cl}$ & $\mathrm{H}$ & $\mathrm{SCH}_{2} \mathrm{CH}_{2} \mathrm{NH}_{2}$ & $\mathrm{Me}$ & $\mathbf{2 d}$ \\
$\mathbf{1 i}$ & $\mathrm{C}$ & $\mathrm{Cl}$ & $\mathrm{H}$ & $\mathrm{SCH}_{2} \mathrm{CH}_{2} \mathrm{NH}_{2}$ & $\mathrm{H}$ & $\mathbf{2 e}$ \\
$\mathbf{1 j}$ & $\mathrm{C}$ & $\mathrm{Cl}$ & $\mathrm{H}$ & $\mathrm{SCH}_{2} \mathrm{CH}_{2} \mathrm{NH}_{2}$ & $\mathrm{NH}$ & $\mathbf{2 f}$ \\
\hline
\end{tabular}

* Corresponding author: gtakim@lgls.co.kr 
Scheme 1 .

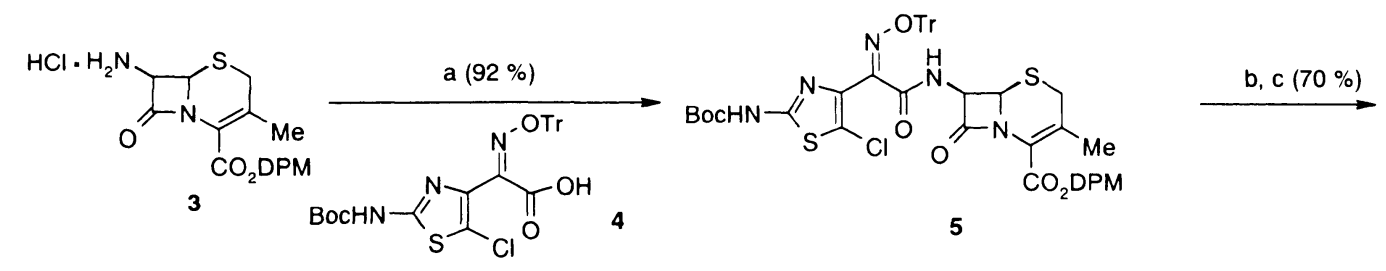<smiles>CC(C)(C)OC(=O)Nc1nc(/C(=N/[O-])C(=O)NC2C(=O)N3C(C(=O)O[Na])=C(CC=O)CSC23)c(Cl)s1</smiles>

6<smiles>CCO/N=C(\C(=O)NC1C(=O)N2C(C(=O)O[Na])=C(/C=C/O)CSC12)c1nc(NC(=O)OCc2ccccc2)sc1Cl</smiles><smiles>Nc1nc(O)cc(S/C=C/C2=C(C(=O)O)N3C(=O)C(NC(=O)/C(=N\O)c4nc(N)sc4Cl)C3SC2)n1</smiles>

a) $\mathrm{POCl}_{3}$, pyridine, $\mathrm{CH}_{2} \mathrm{Cl}_{2},-20^{\circ} \mathrm{C}$; b) t- $\mathrm{BuOCH}\left(\mathrm{NMe}_{2}\right)_{2}, \mathrm{DMF}, 50^{\circ} \mathrm{C}$; c) $1 \mathrm{~N} \mathrm{HCl}$, ethyl acetate, rt; d) $\mathrm{Tf}_{2} \mathrm{O}$,

pyridine, $\mathrm{CH}_{2} \mathrm{Cl}_{2},-2{ }^{\circ} \mathrm{C}$; e) DMF:DMSO $=2: 1$, pyrimidinethiols, $\mathrm{rt}$; f) $\mathrm{CF}_{3} \mathrm{COOH}, \mathrm{Et}_{3} \mathrm{SiH}$, anisole

Abbreviation: DPM= diphenylmethyl, Tr=trityl

Scheme 2 .

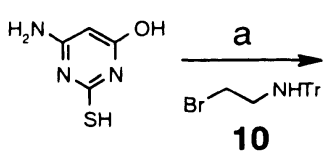

9<smiles>CCNCCSc1nc(N)cc(O)n1</smiles>

11

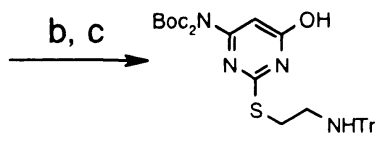

12

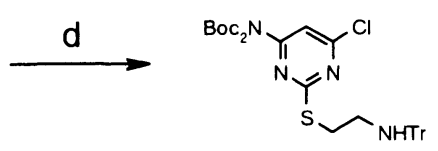

13

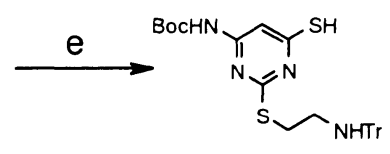

$2 f$

a) $\mathrm{DMF}, \mathrm{H}_{2} \mathrm{O}, \mathrm{Et}_{3} \mathrm{~N}$; b) $\mathrm{Et}_{3} \mathrm{~N}, \mathrm{Boc}_{2} \mathrm{O}, \mathrm{CH}_{2} \mathrm{Cl}_{2}$; c) $\mathrm{EtOH}, \mathrm{NaOH}$; d) oxalyl chloride, DMF(cat.), $\mathrm{CH}_{2} \mathrm{Cl}_{2}$; e) $\mathrm{EtOH}, \mathrm{NaSH}$

8 in good yield $(50 \sim 80 \%)$, and then deprotection with trifluoroacetic acid afforded $\mathbf{1 c}$. For the preparation of $\mathbf{1 j}$, pyrimidine $\mathbf{2 f}$ with a basic chain could be synthesized as shown in Scheme 2. The commercially available pyrimidinethiol 9 was subjected to bromide 10, followed by protection with $\mathrm{Boc}_{2} \mathrm{O}$ and selective hydrolysis with sodium 
hydroxide. Vilsmeyer reaction of bis-Boc protected amine 12 with oxalyl chloride in the presence of DMF afforded 13. Displacement of $\mathbf{1 3}$ with sodium sulfide and the concomitant deprotection of Boc group furnished $\mathbf{2 f}$. Cephalosporins 1a, $\mathbf{1 b}$ and $\mathbf{1 d} \sim \mathbf{g}$ were prepared by using the same procedure of the formation of 1c. Spectra data of 1c were given as below.

Spectra for 1c: ${ }^{1} \mathrm{H}$ NMR (400 MHz, DMSO- $\left.d_{6}\right) \delta 11.58$ $(1 \mathrm{H}, \mathrm{s}), 9.30(1 \mathrm{H}, \mathrm{d}, J=8 \mathrm{~Hz}), 7.20 \sim 7.00(2 \mathrm{H}$, br s $), 7.10$ $(1 \mathrm{H}, \mathrm{d}, J=16 \mathrm{~Hz}), 6.95(1 \mathrm{H}, \mathrm{d}, J=16 \mathrm{~Hz}), 6.76 \sim 6.64(2 \mathrm{H}$, brs), $5.64(1 \mathrm{H}, \mathrm{dd}, J=8.8 \mathrm{~Hz}, 4.6 \mathrm{~Hz}), 5.48(1 \mathrm{H}, \mathrm{s}), 5.01$ $(1 \mathrm{H}, \mathrm{d}, J=4.8 \mathrm{~Hz}), 3.84(1 \mathrm{H}, \mathrm{d}, J=17.6 \mathrm{~Hz}), 3.49(1 \mathrm{H}, \mathrm{d}$, $J=17.6 \mathrm{~Hz})$; MS $m / z 571(\mathrm{M}+1)^{+}$.

Spectra for 1f: ${ }^{1} \mathrm{H}$ NMR $\left(500 \mathrm{MHz}, \mathrm{D}_{2} \mathrm{O}\right) \delta 11.58(1 \mathrm{H}$, s), $9.30(1 \mathrm{H}, \mathrm{d}, J=8 \mathrm{~Hz}), 7.20 \sim 7.00(2 \mathrm{H}, \mathrm{br} \mathrm{s}), 7.10(1 \mathrm{H}, \mathrm{d}$, $J=16 \mathrm{~Hz}), 6.95(1 \mathrm{H}, \mathrm{d}, J=16 \mathrm{~Hz}), 6.76 \sim 6.64(2 \mathrm{H}, \mathrm{brs})$, $5.64(1 \mathrm{H}, \mathrm{dd}, J=8.8 \mathrm{~Hz}, 4.6 \mathrm{~Hz}), 5.48(1 \mathrm{H}, \mathrm{s}), 5.01(1 \mathrm{H}, \mathrm{d}$, $J=4.8 \mathrm{~Hz}), \quad 3.84(1 \mathrm{H}, \quad \mathrm{d}, J=17.6 \mathrm{~Hz}), 3.49(1 \mathrm{H}, \mathrm{d}$, $J=17.6 \mathrm{~Hz}) ; \mathrm{MS} m / z 571(\mathrm{M}+1)^{+}$.

Spectra for $1 \mathbf{j}$ : ${ }^{1} \mathrm{H}$ NMR $\left(500 \mathrm{MHz}, \mathrm{DMSO}-d_{6}\right) \delta 7.05$ $(1 \mathrm{H}, \mathrm{d}, J=16 \mathrm{~Hz}), 6.65(1 \mathrm{H}, \mathrm{d}, J=16 \mathrm{~Hz}), 6.07(1 \mathrm{H}, \mathrm{s})$, $5.65 \sim 5.64(1 \mathrm{H}, \mathrm{m}), 5.04(1 \mathrm{H}, \mathrm{d}, J=5 \mathrm{~Hz}), 3.25 \sim 3.07(6 \mathrm{H}$, $\mathrm{m})$; MS $m / z 629(\mathrm{M}+1)^{+}$.

\section{Antibacterial Activities and Discussion}

Agar dilution method was used to determine the minimal inhibitory concentration (MIC) of compounds against the selected organisms. The MIC values for vancomycin are shown for comparison. In general all the compounds showed good activities against Gram-positive strains except $\mathbf{1 a}$ and $\mathbf{1 b}$, in which antibacterial activities against MRSA were poorly active $(32 \mu \mathrm{g} / \mathrm{ml}, 8 \mu \mathrm{g} / \mathrm{ml})$. Installation of chloride at an aminothiazole ring resulted in improved antibacterial activities in 1c, 1d, 1e and 1f significantly. Among those cephalosporins, 1c, 1d and 1f having the same aminothiazole ring and the different pyrimidine rings exhibited excellent and well-balanced antibacterial activities against MRSA, MRSE and vancomycin-resistant Enterococcus faecalis. Especially, antibacterial activities of 1c having 2-amino-4-hydroxy-substituted pyrimidine against MRSA were comparable to those of vancomycin, and antibacterial activities of 1c against all the MRSE strains were twice more active than those of vancomycin. In addition, cephalosporin 1c displayed excellent activity against vancomycin-resistant E. faecalis 2009 (MIC: $0.25 \mu \mathrm{g} / \mathrm{ml}$ ). Cephalosporin 1f with 2-hydroxy-4-aminosubstituted pyrimidine also possessed good activities against Gram-positive strains. When $R_{2}$ was introduced with bulky group like cyclopentyl group in 1e, 1e was twice to four times less active against MRSA than cephalosporin 1c. Switching an aminothiazole ring in 1c with an aminothiadiazole ring in $\mathbf{1 g}$ resulted in the reduction of in-vitro antibacterial activities against all the Gram-positive strains in Table 1.

A. CHO et al. reported that the incorporation of a basic aminopyridine at C-7 position afforded good potency against MRSA and acceptable solubility for intravenous administration. ${ }^{9)}$ When $\mathbf{1 h}, \mathbf{1} \mathbf{i}$ and $\mathbf{1 j}$ attached with a basic chain in pyrimidines were tested, they showed excellent antibacterial activities against all the Gram-positive strains in Table 1 respectively. Especially $\mathbf{1 j}$ was highly active against MRSA and twice more active against MRSE and VREF than 1c. Overall, most of the cephalosporins 1 with the (E)-thiovinyl linker attached pyrimidines were found to show excellent and well-balanced activities against Gram-

Table 1. Antibacterial activities of cephalosporins (MIC, $\mu \mathrm{g} / \mathrm{ml}$ ).

\begin{tabular}{cccccccccccc}
\hline compound & $\mathbf{1 a}$ & $\mathbf{1 b}$ & $\mathbf{1 c}$ & $\mathbf{1 d}$ & $\mathbf{1 e}$ & $\mathbf{1 f}$ & $\mathbf{1 g}$ & $\mathbf{1 h}$ & $\mathbf{1 i}$ & $\mathbf{1 j}$ & Vancomycin \\
\hline S.a.1 & 32 & 8 & 1 & 2 & 4 & 1 & 4 & 2 & 2 & 1 & 2 \\
S.a.2 & 32 & 8 & 0.5 & 1 & 2 & 0.5 & 2 & 2 & 2 & 1 & 2 \\
S.a.3 & 32 & 8 & 1 & 1 & 2 & 1 & 4 & 1 & 4 & 1 & 0.5 \\
S.a.4 & 32 & 8 & 1 & 1 & 2 & 1 & 4 & 2 & 4 & 1 & 0.5 \\
S.a.5 & 32 & 8 & 0.5 & 1 & 2 & 1 & 2 & 2 & 2 & 1 & 0.5 \\
S.e.1 & 32 & 2 & 0.5 & 1 & 2 & 0.5 & 1 & 0.5 & 1 & 0.25 & 1 \\
S.e.2 & 16 & 2 & 0.5 & 1 & 1 & 0.5 & 2 & 0.5 & 1 & 0.25 & 1 \\
S.e.3 & 64 & 16 & 0.5 & 1 & 1 & 1 & 4 & 1 & 2 & 0.5 & 1 \\
E.f.1 & 32 & 0.5 & 0.25 & 0.5 & 2 & 0.25 & 1 & 0.25 & 0.5 & 0.13 & $>64$ \\
E.f.2 & 8 & 0.25 & 0.25 & 0.5 & 2 & 0.25 & 1 & 0.25 & 0.5 & 0.13 & 1 \\
\hline
\end{tabular}

Abbreviation: Sa.1:methicillin-resistant Staphylococcus aureus 241, S.a.2:methicillin-resistant Staphylococcus aureus K311, S.a.3:methicillinresistant Staphylococcus aureus K364, S.a.4:methicillin-resistant Staphylococcus aureus K367, S.a.5:methicillin-resistant Staphylococcus aureus K372, S.e.1: methicillin-resistant Staphylococcus epidermidis 887E1, S.e.2: methicillin-resistant Staphylococcus epidermidis R005, S.e.3: methicillinresistant Staphylococcus epidermidis R025, E.f.1:vancomycin-resistant Enterococcus faecalis 2009, E.f.2:Enterococcus faecalis EFS004 
Table 2. Protective effect against MRSA K283 systemic infection.

\begin{tabular}{ccc}
\hline compound & PD $_{50}(\mathrm{mg} / \mathrm{kg})$ & $\mathrm{MIC}(\mu \mathrm{g} / \mathrm{ml})$ \\
\hline 1c & 7.5 & 1 \\
1d & 9.8 & 2 \\
1e & $>30$ & 2 \\
1f & 4.7 & 1 \\
1h & 9 & 2 \\
$\mathbf{1 i}$ & $>30$ & 2 \\
1j & 2.5 & 1 \\
Vancomycin & 2.5 & 1 \\
\hline
\end{tabular}

Systemic infection was caused by methicillin-resistant $S$. aureus K283 in 4-week-old male mice (18 21 g) by injection a single $0.5 \mathrm{ml}$ inoculum containing various lethal doses of bacteria, intraperitoneally. Control and treatment group at each dose were composed of 6 mice each. The $50 \%$ protective dose $\left(\mathrm{PD}_{50}\right.$, $\mathrm{mg} / \mathrm{kg}$ ) was calculated by Probit analysis from the survival rates on day 5 after the infection. Compounds were administrated subcutaneously with $5 \mathrm{~min}$ interval and $2 \mathrm{~h}$ interval after infection.

positive strains.

Based on the MIC values, cephalosporins 1c, 1d, 1e, 1f, $\mathbf{1 h}, \mathbf{1} \mathbf{i}$ and $\mathbf{1 j}$ were selected to adjust the systemic infection model against MRSA K283 for the further evaluation as shown in Table 2. Among them, 1e and 1i displayed disappointing in vivo activities due to low pharmacokinetic profile in mice. 1c, $1 \mathbf{d}$ and $1 \mathbf{f}$ showed moderate in vivo activity but inferior in vivo activity to vancomycin although they have good in vitro activity against MRSA K283. Cephalosporin $\mathbf{1 j}$ having a basic chain in pyrimidine was proven to exhibit almost the same in vivo activity $\left(\mathrm{PD}_{50}\right.$ : $2.5 \mathrm{mg} / \mathrm{kg}$ ) with vancomycin in this model. Among them, intravenous administration of $\mathbf{1 c}, \mathbf{1 f}$ and $\mathbf{1 j}$ in rats with $20 \mathrm{mg} / \mathrm{kg}$ resulted in AUC ( $\mathrm{mg} \mathrm{min} / \mathrm{ml})$ of 4972, 5573 and 924 , and half time (minute) of 47, 55 and 16, respectively.

1c, $1 \mathbf{f}$ and $\mathbf{1 j}$ were selected for the further investigation as our new candidates against nosocomial infection based on in vivo experiment and pharmacokinetic data.

In conclusion, cephalosporin having the (E)-2-thiovinyl linker attached with pyrimidines at $\mathrm{C}-3$ position was found to possess excellent in vitro activities and good in vivo activity against MRSA, MRSE and VREF.

\section{Acknowledgments}

We would like to thank the pharmacokinetic group (Dr. Sunwha LeE and Ms. Jung Eun SHIN) for providing the pharmacokinetic data and preformulation group (Dr. AERI KIM and $\mathrm{KI}$-SoOK PARK) for preparing the samples for in vivo experiment.

\section{References}

1) Ayliffe, G. A. J.: The progressive intercontinental spread of methicillin-resistant Staphylococcus aureus. Clinical Infectious Diseases 24: S74 79, 1997

2) EHLERT, K.: Methicillin-resistance in Staphylococcus aureus-molecular basis, novel targets and antibiotic therapy. Curr. Pharm. Des. 5: 45 55, 1999

3) Bryson, H. M. \& C. M. SPENCER: Quinupristindalfopristin. Drugs 52: 406 415, 1996

4) Diekema, D. J. \& R. N. Jones: Oxazolidinone antibiotics. Lancet 358: 1975 1982, 2001

5) Mutnick, A. H.; V. EnNe \& R. N. Jones: Linezolid resistance since 2001: SENTRY Antimicrobial surveillance program. Ann. Pharmacother. 37: 909 911, 2003

6) Hanaki, H.; H. Akagi, Y. Masaru, T. Otani, A. Hyodo \& K. HiRAMATSU: TOC-39, a novel parenteral broadspectrum cephalosporin with excellent activity against methicillin-resistant Staphylococcus aureus. Antimicrob. Agents Chemother. 39: 1120 1126, 1995

7) LeE, C.-S.; E.-J. Ryu, S. H. OH, K.-S. PAEK, M. Y. KIM \& H. Youn: Synthesis and antibacterial activities of novel C(3)-aminopyrimidinyl substituted cephalosporins including against respiratory tract pathogens. Bioorg. Med. Chem. Lett. 10: 2123 2127, 2000 (Preparation of pyrimidinethiol $\mathbf{2 a}, \mathbf{2 b}$ and $\mathbf{2 c}$ was cited in this reference.)

8) ABdulla, R. F. \& R. S. BRINKMEYER: The chemistry of formamide acetals. Tetrahedron 35: 1675 1735, 1979

9) Cho, A.; T. W. Glinka, M. Ludiwikow, A. T. Fan, M. WANG \& S. J. HECKER: New anti-MRSA cephalosporins with a basic aminopyridine at the $\mathrm{C}-7$ position. Bioorg. Med. Chem. Lett. 11: 137 140, 2001 